Article

\title{
Towards Better Grafting: SCoT and CDDP Analyses for Prediction of the Tomato Rootstocks Performance under Drought Stress
}

\author{
Mohamed M. El-Mogy ${ }^{1}\left(\mathbb{D}\right.$, Mohamed A. M. Atia ${ }^{2,+}{ }^{(D}$, Faten Dhawi ${ }^{3}\left(\mathbb{D}\right.$, Ahmed S. Fouad $^{4,+(D)}$, \\ Eslam S. A. Bendary ${ }^{3,5}{ }^{(D}$, Ebtihal Khojah ${ }^{6}$, Bassem N. Samra ${ }^{7}$ (D), Karima F. Abdelgawad ${ }^{1}$, \\ Mohamed F. M. Ibrahim ${ }^{8}\left(\right.$ D) and Emad A. Abdeldaym ${ }^{1, *(D)}$
}

check for updates

Citation: El-Mogy, M.M.; Atia, M.A.M.; Dhawi, F.; Fouad, A.S.; Bendary, E.S.A.; Khojah, E.; Samra, B.N.; Abdelgawad, K.F.; Ibrahim, M.F.M.; Abdeldaym, E.A. Towards Better Grafting: SCOT and CDDP Analyses for Prediction of the Tomato Rootstocks Performance under Drought Stress. Agronomy 2022, 12, 153. https://doi.org/ 10.3390/agronomy12010153

Academic Editors

Youssef Rouphael, Giuseppe Colla and Marios Kyriacou

Received: 4 December 2021

Accepted: 3 January 2022

Published: 8 January 2022

Publisher's Note: MDPI stays neutral with regard to jurisdictional claims in published maps and institutional affiliations.

Copyright: (c) 2022 by the authors Licensee MDPI, Basel, Switzerland. This article is an open access article distributed under the terms and conditions of the Creative Commons Attribution (CC BY) license (https:// creativecommons.org/licenses/by/ $4.0 /)$
1 Vegetable Crops Department, Faculty of Agriculture, Cairo University, Giza 12613, Egypt; elmogy@agr.cu.edu.eg (M.M.E.-M.); karima.abdelgawad@agr.cu.edu.eg (K.F.A.)

2 Molecular Genetics and Genome Mapping Laboratory, Genome Mapping Department, Agricultural Genetic Engineering Research Institute (AGERI), Agricultural Research Center (ARC), Giza 12619, Egypt; matia@ageri.sci.eg

3 Agricultural Biotechnology Department, College of Agricultural and Food Sciences, King Faisal University, P.O. Box 420, Al-Ahsa 31982, Saudi Arabia; falmuhanna@kfu.edu.sa (F.D.); esslam136@gmail.com (E.S.A.B.)

4 Botany and Microbiology Department, Faculty of Science, Cairo University, Giza 12613, Egypt; ahmedsfouad@yahoo.com

5 Agricultural Biochemistry Department, Faculty of Agriculture, Ain Shams University, Cairo 11241, Egypt

6 Department of Food Science and Nutrition, College of Science, Taif University, P.O. Box 11099, Taif 21944, Saudi Arabia; eykhojah@tu.edu.sa

7 Department of Biology, College of Science, Taif University, P.O. Box 11099, Taif 21944, Saudi Arabia; b.elsayed@tu.edu.sa

8 Department of Agricultural Botany, Faculty of Agriculture, Ain Shams University, Cairo 11566, Egypt; ibrahim_mfm@agr.asu.edu.eg

* Correspondence: emad.abdeldaym@agr.cu.edu.eg; Tel.: +20-010-1570-0774

+ These authors contributed equally to this work.

Abstract: This study aims to predict the behavior of different tomato rootstocks under drought stress conditions. SCOT and CDDP analyses were employed to characterize the genetic relatedness among a commercial drought-sensitive tomato hybrid (cv. Bark) and four wild tomato accessions (LA2711, LA1995, LA3845, and LA4285) known for their tolerance to adverse conditions. The Bark plants were grafted onto the aforementioned wild accessions and self-grafted as control, and then the behavior of all graft unions was followed under normal and drought stress conditions. Our results showed a general genotype-dependent better growth and yield of heterografts than autografts under all growth conditions. Furthermore, clustering analysis based on growth, yield quantity and quality traits, and the leaf content of minerals, ABA, GA3, and proline, in addition to the activity of APX, POD, and DHAR reflected the same grouping pattern of the studied rootstocks exhibited by SCoT and CDDP. The identical grouping pattern supports the utilization of SCOT and CDDP as a robust screening tool helpful to predict the physiological and agronomical behavior of grafting on different tomato rootstocks. Furthermore, grafting could be a cost-efficient alternative method to improve drought tolerance in sensitive tomato genotypes.

Keywords: Solanum lycopersicum L.; rootstocks; yield; ABA; GA3; proline; APX; POD; DHAR; plant growth; fruit quality

\section{Introduction}

Tomato (Solanum lycopersicum L.) is a major vegetable crop grown worldwide due to its commercial and health relevance. Based on a statement by the FAO in 2020 (http:/ / faostat.fao.org/, accessed on 20 December 2021), the world production of tomato was about 186 million tons harvested from 5 million hectares. Tomato fruit contains an appreciable 
amount of essential minerals and antioxidants including lycopene pigment and vitamin $C$ which can reduce the progression of various types of cancer [1].

Drought occurs when the plant water requirement cannot be fully fulfilled [2]. Water is the most abundant component of the plant body comprising $80-95 \%$ of fresh biomass and plays a fundamental role in nearly all physiological aspects of plant metabolism, growth and development $[3,4]$. Unfortunately, global climate change consistently results in prevailing drought conditions over vast global areas [5]. It is estimated that about two-thirds of the global population will reside in areas suffering from water deficiencies by the end of the first quarter of this century [6].

Generally, drought stress is usually associated with declined cell enlargement and cell proliferation rates, reduction in foliage dimensions and shoot height, alteration in stomatal activities, and limited nutrient uptake resulting in declined plant yield [7]. In addition, water deficiency normally reduces the turgor pressure of guard cells, resulting in subsequent stomatal closure that carries with it membrane damage and anomalous functioning enzymes, specifically those involved in ATP synthesis, in reducing photosynthetic activities $[7,8]$. Drought stress conditions also provoke the generation of reactive oxygen species (ROS) disrupting cellular redox regulatory functioning [9].

Water deficit conditions trigger several defense responses to enhance water use efficiency and to mitigate drought-induced damages [2]. Stomatal closure is one of the earliest responses to drought conditions that are achieved in close relation to elevated levels of ABA and $\mathrm{K}^{+}[10]$. In addition, stressed plants gradually develop advanced drought tolerance strategies including encouragement of biosynthesis of compatible solutes and enhancement of the enzymatic and non-enzymatic components of the antioxidant apparatus [11].

At the morphological level, the root is the major driver of water in most plant forms; therefore, it is an important feature prompting plant response to drought stress [12]. Consequently, grafting onto drought-tolerant rootstocks is used as an alternative to breeding for drought management. To save time and effort spent in trials with functionally similar rootstocks, an efficient screening tool to highlight the functionally similar/different genotypes concerning drought tolerance is crucial. Grafting success depends on many factors, among which genotypic factors are the most important for compatibility or incompatibility of the rootstock and scion [13]. It was used successfully to manage drought stress in tomato plants $[14,15]$. However, all investigations lacked genetic characterization of scion and rootstock necessary for their reproducibility and generalization.

Genetic variations in tomatoes can be characterized rapidly, accurately, and efficiently by utilizing molecular markers [16]. Various random molecular marker techniques have been employed in tomatoes, such as ISSR, RAPD, and AFLP, which do not require prior knowledge of the genome sequence and highlight high polymorphism levels. However, DNA markers such as SNP and SSR are developed based on high-throughput analysis and mining of the whole sequenced genome. Notably, these markers can be positioned far from the gene(s) of interest, which might be independent of the trait/phenotype of interest. Therefore, functional markers represent potential alternative approaches compared to DNA markers scattered randomly through the genome $[16,17]$.

As a result of the tremendous increase in genomic studies, many functional molecular markers were released and applied in several research areas over the past few years. These markers have been introduced as a modern trend to develop a novel set of genetargeting molecular marker techniques that are more robust and effective than random marker systems [18]. Due to the availability of massive genomic databases, growth in the development novel marker systems positioned close to or inside the area of the gene or regulatory elements has become more straightforward [19]. These novel gene-targeting marker systems have diverse applications, including molecular phylogeny, genetic conservation, genetic diversity, developmental biology, and molecular ecology. Ten years ago, Collard and Mackill [20] developed two of the most powerful gene-targeting marker systems in plants. These systems are termed Start Codon Targeted Polymorphism (SCoT) and Conserved DNA-Derived Polymorphism (CDDP). The first technique depends on the 
conserved regions flanking the start codon (ATG) of genes while the second is based on sequences encoding short conserved amino acid chains within plant proteins. Both techniques depend on primers with a relatively high annealing temperature that improves their reproducibility and genetic resolving potential. Therefore, these markers can be utilized to characterize the genetic relatedness among different genotypes and predict relations among the corresponding phenotypes.

This study aimed to assess the potential use of two potent gene-targeting markers (SCoT and CDDP) to resolve genetic relatedness among different tomato rootstocks in relation to the phenotypic, physiological, and agronomical performance of their graft unions with a drought-sensitive tomato scion under three drought regimes.

\section{Materials and Methods}

\subsection{Plant Material and Grafting}

Four tomato accessions (LA2711 (RS1), LA1995 (RS2), LA3845 (RS3) and LA4285 (RS4) known for their tolerance to adverse conditions (salinity, drought, and diseases) were obtained from the International Tomato Genetic Resources Centre in the USA, in addition to a commercial local (Egyptian) hybrid namely the Bark, were utilized in this study. The characteristics of used accessions are presented in Supplementary Table S1. The Bark seedlings (at one true-leaf stage) were grafted onto the aforementioned wild accessions and self-grafted as control. The grafted seedlings were kept under shading conditions at temperatures $30 \pm 2{ }^{\circ} \mathrm{C}$ and $90-95 \%$ relative humidity (RH) in a controlled greenhouse.

\subsection{Molecular Markers Analysis}

\subsubsection{Purification of Tomato DNA}

Genomic DNA was purified from fresh leaves $(100 \mathrm{mg})$ of the four heterografts (RS1, RS2, RS3, and RS4) in addition to the Bark (self-grafted; control) using the DNeasy Plant Mini Kit (QIAGEN, Santa Clarita, CA, USA), according to the manufacturer's protocol. The DNA concentrations were measured using the Qubit ${ }^{\circledR}$ 3.0 Fluorometer (Thermo Fisher Scientific Inc., Waltham, MA, USA). Finally, DNA concentrations were normalized to $10 \mathrm{ng} / \mu \mathrm{L}$ in all samples to be used in all subsequent molecular analyses.

\subsubsection{CDDP-PCR Analysis}

The CDDP-PCR amplification was done according to the protocol of Collard and Mackill [20]. Eleven CDDP primers (Table 1) were used against the five tomato samples (RS1, RS2, RS3, RS4, and the Bark). The volume of PCR reaction was $25 \mu \mathrm{L}$ including $1 \mathrm{X}$ PCR reaction buffer, $1 \mu \mathrm{M}$ of primer, $1.5 \mathrm{mM}$ of $\mathrm{MgCl}_{2}, 0.2 \mu \mathrm{M}$ of dNTPs mix, 1 unit of Go-Taq Flexi polymerase (Promega, Madison, WI, USA), and $25 \mathrm{ng}$ of genomic DNA. The PCR cycles were programmed as follows: an initial denaturing at $94{ }^{\circ} \mathrm{C}$ for $3 \mathrm{~min}$, and then 35 cycles of $94{ }^{\circ} \mathrm{C}$ for $1 \mathrm{~min}, 50^{\circ} \mathrm{C}$ for $1 \mathrm{~min}$, and $72{ }^{\circ} \mathrm{C}$ for $2 \mathrm{~min}$; the final extension was set up for $5 \mathrm{~min}$. The CDDP-PCR products were resolved on $1.5 \%$ agarose gels, then photographed using the Gel Doc XR+ Gel Documentation System (Bio-Rad Laboratories, Inc., Hercules, CA, USA). 
Table 1. CDDP Primers code, sequence, conserved targets, and details.

\begin{tabular}{|c|c|c|c|c|c|c|}
\hline $\begin{array}{l}\text { Primer } \\
\text { Code }\end{array}$ & Primer Sequence & Gene & Gene Function & $\begin{array}{l}\text { Amino Acid } \\
\text { Motif }\end{array}$ & Length & GC \\
\hline CDDP-1 & TGGCGSAAGTACGGCCAG & \multirow{3}{*}{ WRKY } & \multirow{3}{*}{$\begin{array}{l}\text { Transcription factor for developmental and } \\
\text { physiological roles }\end{array}$} & WRKYGQ & 18 & 67 \\
\hline CDDP-2 & GTGGTTGTGCTTGCC & & & GKHNH & 15 & 60 \\
\hline CDDP-3 & GCCCTCGTASGTSGT & & & TTYEG & 15 & 67 \\
\hline CDDP-4 & GGCAAGGGCTGCCGC & \multirow{2}{*}{ MYB } & \multirow{2}{*}{$\begin{array}{l}\text { Implicated in secondary metabolism, abiotic } \\
\text { and biotic stresses, cellular morphogenesis }\end{array}$} & GKSCR & 15 & 80 \\
\hline CDDP-5 & GGCAAGGGCTGCCGG & & & GKSCR & 15 & 80 \\
\hline CDDP-6 & AAGGGSAAGCTSCCSAAG & \multirow{3}{*}{ KNOX } & Homeobox genes that function as & KGKLPK & 18 & 61 \\
\hline CDDP-7 & CACTGGTGGGAGCTSCAC & & transcription factors with a unique & HWWELH & 18 & 67 \\
\hline CDDP-8 & AAGCGSCACTGGAAGCC & & homeodomain & KRHWKP & 17 & 65 \\
\hline CDDP-9 & ATGGGCCGSGGCAAGGTGC & \multirow{2}{*}{ MADS } & Involved in controlling floral organ initiation & MGRGKV & 19 & 74 \\
\hline CDDP-10 & CTSTGCGACCGSGAGGTC & & and development & LCDAEV & 18 & 72 \\
\hline CDDP-11 & ACSCCSATCCACCGC & ABP1 & Auxin-binding protein & TPIHR & 15 & 73 \\
\hline
\end{tabular}

\subsubsection{SCoT-PCR Analysis}

The SCoT-PCR amplification was accomplished according to the protocol of Collard and Mackill [20]. Fifteen SCoT primers were used to characterize the five tomato samples (Table 2). The PCR reaction was carried out in a total volume $25 \mu \mathrm{L}$ including $1 X$ PCR reaction buffer, $1 \mu \mathrm{M}$ of primer, $0.2 \mu \mathrm{M}$ of dNTPs mix, $1.5 \mathrm{mM}$ of $\mathrm{MgCl}_{2}, 1$ unit of G2 Go-Taq Flexi polymerase (Promega), and $30 \mathrm{ng}$ of genomic DNA. The PCR cycles were set as follows: an initial denaturing at $94^{\circ} \mathrm{C}$ for $3 \mathrm{~min}$, then 35 cycles $\left(94{ }^{\circ} \mathrm{C}\right.$ for $1 \mathrm{~min}, 50{ }^{\circ} \mathrm{C}$ for $1 \mathrm{~min}$, and $72{ }^{\circ} \mathrm{C}$ for $90 \mathrm{~s}$ ), and final extension step at $72{ }^{\circ} \mathrm{C}$ for $7 \mathrm{~min}$. The PCR products were electrophoresed using 1.5\% agarose gel, then visualized using the Gel Doc XR+ Gel Documentation System (Bio-Rad Laboratories, Inc.).

Table 2. SCoT primers code, sequence, and details.

\begin{tabular}{ccc}
\hline Primer Code & Primer Sequence & $\%$ \\
\hline SCoT-1 & GC \\
SCoT-2 & CAACAATGGCTACCACCA & 50 \\
SCoT-3 & CACCATGGCTACCACCAG & 61 \\
SCoT-4 & CAACAATGGCTACCACCG & 56 \\
SCoT-5 & CAACAATGGCTACCACCT & 50 \\
SCoT-6 & CAACAATGGCTACCACGA & 50 \\
SCoT-1 & CAACAATGGCTACCACGC & 56 \\
SCoT-8 & ACCATGGCTACCACCGGG & 67 \\
SCoT-9 & CAACAATGGCTACCACGT & 50 \\
SCoT-10 & CAACAATGGCTACCAGCA & 50 \\
SCoT-11 & CAACAATGGCTACCAGCC & 56 \\
SCoT-12 & AAGCAATGGCTACCACCA & 50 \\
SCoT-13 & ACGACATGGCGACCAACG & 61 \\
SCoT-14 & ACGACATGGCGACCATCG & 61 \\
SCoT-15 & ACGACATGGCGACCACGC & 67 \\
\hline
\end{tabular}

\subsubsection{Molecular Data Analysis}

For the data analysis, the distinguishable and clear bands were visually scored to diminish errors. To build a binary data matrix, the bands were scored as (1) for present or (0) for absent. The percentage of polymorphism was calculated by dividing the total number of polymorphic bands by the total number of bands for each primer.

Jaccard's coefficient was used to calculate genetic similarity levels [21]. The UPGMAbased dendrograms were constructed for both SCoT and CDDP techniques and lastly visualized using the Interactive Tree Of Life (iTOL) tool [22]. Finally, principal component analysis (PCA) was calculated using a D center module [23]. 


\subsection{Greenhouse Experiment}

\subsubsection{Growth Conditions}

Two experiments were conducted in a plastic greenhouse $(6 \times 40 \mathrm{~m})$ during the winter of 2018/2019 and 2019/2020 at the Faculty of Agriculture, Cairo University, Giza, Egypt. The average temperature during plant growth was $25 / 18^{\circ} \mathrm{C}$ (day/night), and the mean $\mathrm{RH}$ was $65-73 \%$. The average photon flux density was $800-1000 \mu \mathrm{mol} \mathrm{m} \mathrm{m}^{-2} \mathrm{~s}^{-2}$ during the two growing seasons. Tomato seedlings were transplanted in $6 \mathrm{~L}$ plastic pots filled with a 1:1:1 mixture of peatmoss, vermiculite, and perlite. A drip irrigation system was used to irrigate the individual cultivating row, with one dripper per pot. Three weeks post-transplantation, tomato plants were fertilized weekly with $\mathrm{N}, \mathrm{P}$, and $\mathrm{K}$ through the drip irrigation system; total quantity of N, P, and K applied was about 315,225 , and $450 \mathrm{~kg} \mathrm{ha}^{-1}$; respectively.

\subsubsection{Water Stress Treatments}

Three weeks after transplantation, the irrigation water treatments were applied at the target levels of $100 \%, 75 \%$, and $50 \%$ ETc (ETc = crop evapotranspiration), using drippers with different irrigation rates $(8,6$, and $4 \mathrm{~L} / \mathrm{h})$. The experiment was laid out in a factorial system in a randomized complete design (RCD) with two factors (irrigation water treatments and used rootstocks). The total number of treatments was 15 with six repetitions for each treatment. The different levels of irrigation treatments were continued until the end of the experiment (155 days after seedling transplantation).

\subsubsection{Plant Growth and Yield}

One month after water stress treatments, six representative plants of each treatment were selected randomly to estimate plant growth parameters including shoot fresh and dry weights, leaf chlorophyll content (SPAD), plant height, number of leaves, root length and root fresh and dry weights. Leaf chlorophyll content was determined using a SPAD meter (SPAD 502 Minolta Co., Osaka, Japan) according to Abdelgawad et al. [24]. The height of the tomato plants was evaluated from the soil surface to the highest growing tip using the meter. Shoots and roots were dried at $75 \pm 2{ }^{\circ} \mathrm{C}$ in a forced-air oven until the constant weight and the dry weights were recorded. Throughout the whole harvesting time for each treatment, the total tomato fruit weight was recorded and converted into total tomato fruit yield per plant.

\subsubsection{Fruit Quality}

Eight tomato fruit samples were collected randomly from each treatment for chemical analyses. Total soluble solids (TSS), and vitamin C (Vit C) were quantified in the homogenized fruit juice according to AOAC [25] techniques. In addition, Vit $C$ content was determined using a titrimetric method with 2,6-dichlorophenol indophenol, and the results were reported as $\mathrm{mg} 100 \mathrm{~g}^{-1} \mathrm{FW}$.

Tomato juice's total soluble solids (TSS) was measured using a digital refractometer (model PR101, Co., Ltd., Tokyo, Japan). A drop of the juice was placed on the lens and the reading was taken in degrees Brix $\left(\mathrm{Bx}^{\circ}\right)$ and expressed as a percentage of soluble solid content in the fruit. Distilled water was used for calibration and the lens was washed twice between samples. Firmness was assessed in red-mature fruits using a Force Gauge Model M4-200 (ELECTROMATIC Equipment Co., Inc. Cedarhurst, NY, USA) with a 1-mm diameter flat probe to measure firmness in red-ripe fruits. The firmness values were expressed in Newtons.

\subsubsection{Leaf Elements Content}

Endogenous essential elements (N, P, K, Ca, Mg and Fe) were assessed in the dried leaves of tomato plants. First, the total nitrogen content of the dried material was assessed using the modified micro-Kjeldahel method as described by AOAC [25]. Next, phosphorus (P) was determined colorimetrically by using the chlorostannous molybdophosphoric blue color method in sulphuric acid according to Piper [26]. Potassium (K) concentrations were 
determined using a flame photometer apparatus (CORNING M 410, Halstead, England). Finally, endogenous $\mathrm{Ca}, \mathrm{Mg}$, and Fe concentrations in tomato leaves were determined using Atomic Absorption Spectrophotometer with air-acetylene, fuel (Pye Unicam, model SP-1900, Radnor, PA, USA).

\subsubsection{Leaf Proline, Gibberellic Acid and Abscisic Acid Content}

The proline content in tomato leaves was assessed using the colorimetric procedure described by Bates et al. [27]. Briefly, approximately $100 \mathrm{mg}$ of freeze-dried samples were homogenized with sulfosalicylic acid (3\%). The homogenate was centrifuged at $14,000 \times g$ for 5 min at room temperature $\left(24^{\circ} \mathrm{C}\right)$ using a centrifuge. A $100 \mu \mathrm{L}$ of supernatant was incubated with a mixture containing $200 \mu \mathrm{L}$ glacial acetic acid and $200 \mu \mathrm{L}$ acidic ninhydrin in a separate tube at $96^{\circ} \mathrm{C}$ for $1 \mathrm{~h}$. The reaction was terminated by transferring the tubes into an ice bath. Then one $\mathrm{mL}$ of toluene was added to the reaction mixture. The resulting chromophore was measured at $520 \mathrm{~nm}$. The proline content was determined using a standard curve and values were expressed as $\mathrm{mmol} \cdot \mathrm{g}^{-1} \mathrm{FW}$.

The concentrations of gibberellic acid $\left(\mathrm{GA}_{3}\right)$ and abscisic acid $(\mathrm{ABA})$ in tomato leaves were determined by the technique stated by Fales et al. [28]. Further details of the extraction, determination and quantification of $\mathrm{GA}_{3}$, and $\mathrm{ABA}$ are reported elsewhere $[29,30]$.

\subsubsection{Leaf Antioxidant Enzymes Content}

The antioxidant enzymes in freeze-dried leaf samples were extracted according to the technique stated by Wang et al. [31]. Briefly, $500 \mathrm{mg}$ of the freeze-dried leaves were milled in liquid nitrogen and mixed in $5 \mathrm{~mL}$ potassium phosphate buffer (100 mM, pH 7.0). Homogenates were then centrifuged at $15,000 \times g$ for $15 \mathrm{~min}$ at $5^{\circ} \mathrm{C}$ and the supernatants were used to assess ascorbate peroxidase (APX, EC 1.11.1.7) and peroxidase (POD, EC 1.11.1.7) using the procedures described by García-Limones et al. [32]. In addition, dehydroascorbate reductase (DHAR, EC 1.8.5.1) activity was determined spectrophotometrically (Hitachi U-1100 spectrophotometer, Tokyo, Japan) according to the method reported by Baier et al. [33]. The activity of enzymes was expressed as $\mathrm{U} \mathrm{min}^{-1} \mathrm{~g}^{-1} \mathrm{FW}$.

\subsection{Clustering Analysis}

Clustering of rootstocks based on phenotypic, physiological, and agronomical criteria was manifested as a heatmap using Clustvis web tool version 1.0 (Metsalu, Tauno and Vilo, Jaak. Clustvis: a web tool for visualizing clustering of multivariate data) [34].

\subsection{Statistical Analysis}

The data of the factorial experiments across two successive seasons 2019 and 2020 were subjected to combined analysis after conducting the normality distribution test [35] and homogeneity test [36]. Furthermore, the obtained data from the combined analysis were subjected to the statistical analysis of variance, and means were compared at the 0.05 level according to Tukey's test using the Statistica 7 program.

\section{Results}

\subsection{Analysis of CDDP and SCoT}

The genetic similarity and degree of polymorphism between the five tomato genotypes were evaluated using eleven CDDP primers (Table 1) and 15 SCoT primers (Table 2). For CDDP-PCR analysis, 195 bands were obtained, and 55 found to be polymorphic (28.2\%). The total number of bands per primer ranged from 15 (primer CDDP-11) to 21 (primer CDDP-10). The number of polymorphic bands per primer ranged from 3 (primer CDDP-11) to 7 (primers CDDP-6), with percentages of polymorphism ranging from $19.0 \%$ (primer CDDP-10) to $37.5 \%$ (primers CDDP-4). The average number of bands/primer was 17.7, while the average number of polymorphic bands/primer was 5.0 (Table 3). 
Table 3. Primer code, the total number of bands, number of polymorphic bands, and percentage of polymorphism in the CDDP and SCoT primers.

\begin{tabular}{|c|c|c|c|}
\hline \multirow{2}{*}{ Code } & \multicolumn{2}{|c|}{ Number of Bands } & \multirow{2}{*}{$\%$ of Polymorphism } \\
\hline & Total & Polymorphic & \\
\hline \multicolumn{4}{|l|}{ CDDP } \\
\hline CDDP-1 & 18 & 4 & 22.2 \\
\hline CDDP-2 & 18 & 6 & 33.3 \\
\hline CDDP-3 & 17 & 5 & 29.4 \\
\hline CDDP-4 & 16 & 6 & 37.5 \\
\hline CDDP-5 & 18 & 5 & 27.8 \\
\hline CDDP-6 & 19 & 7 & 36.8 \\
\hline CDDP-7 & 17 & 6 & 35.3 \\
\hline CDDP-8 & 18 & 4 & 22.2 \\
\hline CDDP-9 & 18 & 5 & 27.8 \\
\hline CDDP-10 & 21 & 4 & 19.0 \\
\hline CDDP-11 & 15 & 3 & 20.0 \\
\hline Total & 195 & 55 & 28.2 \\
\hline Average & 17.7 & 5.0 & \\
\hline \multicolumn{4}{|l|}{ SCoT } \\
\hline SCoT-1 & 21 & 9 & 42.9 \\
\hline SCoT-2 & 15 & 8 & 53.3 \\
\hline SCoT-3 & 15 & 7 & 46.7 \\
\hline SCoT-4 & 16 & 8 & 50.0 \\
\hline SCoT-5 & 19 & 8 & 42.1 \\
\hline SCoT-6 & 21 & 9 & 42.9 \\
\hline SCoT-7 & 13 & 8 & 61.5 \\
\hline SCoT-8 & 17 & 7 & 41.2 \\
\hline SCoT-9 & 13 & 5 & 38.5 \\
\hline SCoT-10 & 16 & 7 & 43.8 \\
\hline SCoT-11 & 18 & 8 & 44.4 \\
\hline SCoT-12 & 17 & 5 & 29.4 \\
\hline SCoT-13 & 16 & 7 & 43.8 \\
\hline SCoT-14 & 20 & 8 & 40.0 \\
\hline SCoT-15 & 19 & 8 & 42.1 \\
\hline Total & 255 & 112 & 43.9 \\
\hline Average & 17.0 & 7.5 & \\
\hline
\end{tabular}

For SCoT-PCR analysis, 255 scorable bands were obtained in total, and 112 were polymorphic (43.9\%). The total number of bands per primer ranged from 13 (primer SCoT9) to 21 (primers SCoT-1 and SCoT-6). In contrast, the number of polymorphic bands per primer ranged from 5 (primers SCoT-9 and SCoT-12) to 9 (primers SCoT-1 and SCoT-6), with percentages of polymorphism ranging from $29.4 \%$ (primer SCoT-12) to $61.5 \%$ (primers SCoT-7). The average number of bands/primer was 17.0, while the average number of polymorphic bands/primer was 7.5 (Table 3 ).

\subsection{Molecular Phylogeny Analysis}

Dendrograms based on UPGMA analysis of CDDP and SCoT data were constructed for the five tomato genotypes. For CDDP analysis, the dendrogram comprised two main clusters; the first cluster included genotypes RS1 and the Bark. While the second cluster is divided into two main sub-clusters; the first involves only the LA3845 (RS3) genotype; meanwhile the second contains the last two genotypes RS2, and RS4 that were the most genetically similar (Figure 1A). 

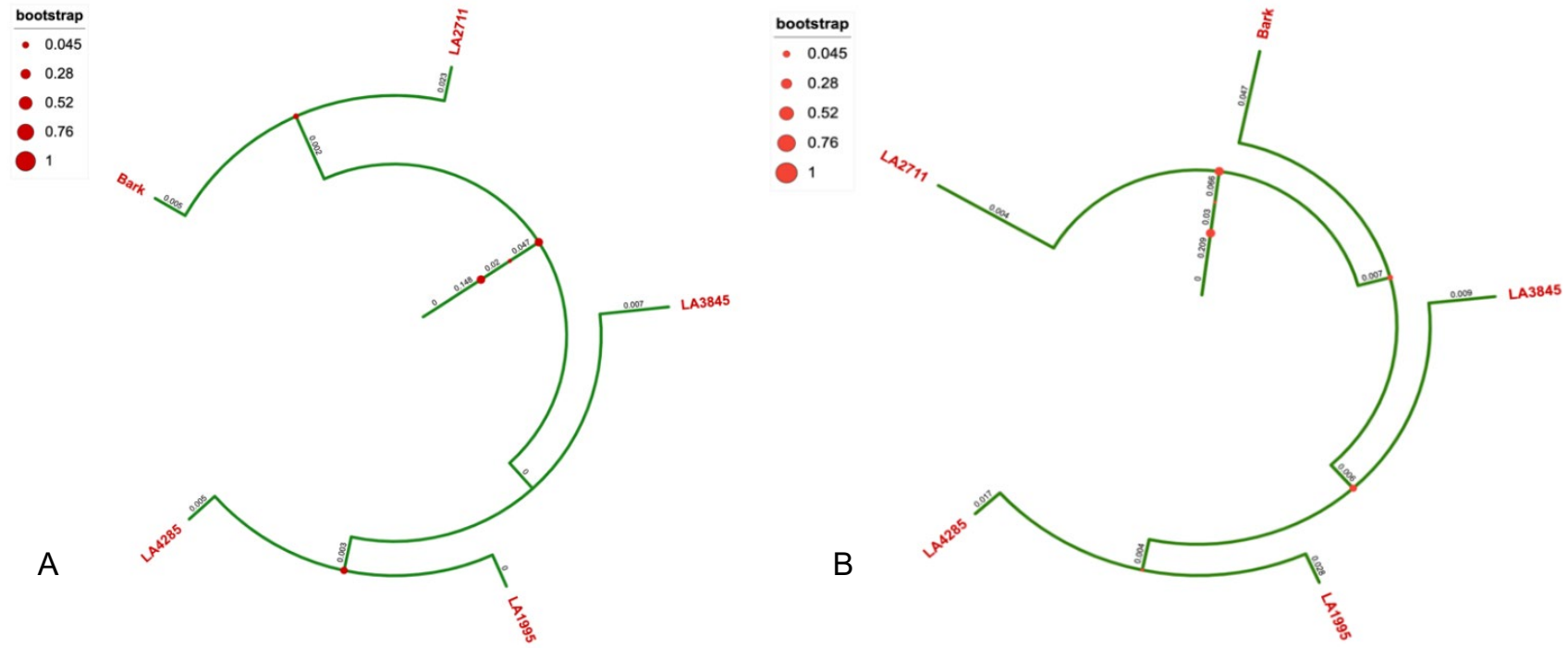

Figure 1. Cluster analysis based on Jaccard's similarity coefficient of the analysis CDDP (A) and SCoT analysis (B) of the five tomato genotypes.

For SCoT analysis, the dendrogram comprised three main clusters. The first and second clusters included genotypes RS1 and the Bark, respectively. While the third cluster split into two main sub-clusters, the first sub-cluster comprised only the RS3 genotype; meanwhile the second sub-cluster contained the last two genotypes RS2, and LA2485 (RS4 that were the most genetically similar (Figure 1B).

On the other hand, the binary scoring generated from CDDP, and SCoT analysis were used to calculate the Jaccard's similarity matrices (Tables 4 and 5, respectively). The CDDP and SCoT similarity matrices values ranged from 76 to $87 \%$, and 75 to $87 \%$, respectively. For CDDP analysis, the highest degree of similarity was observed between RS1 and the Bark with $87 \%$, while the lowest degree of similarity was observed between RS4 and the Bark, and in addition between RS2 and the Bark with 76\%. Meanwhile, for SCoT analysis, the highest degree of similarity was observed between RS2 and RS4 with $87 \%$, while the lowest degree of similarity was observed between RS4 and RS1 with 75\%.

Table 4. Similarity matrix based on the CDDP analysis of the five tomato genotypes.

\begin{tabular}{cccccc}
\hline & RS1 & RS2 & RS3 & RS4 & Bark \\
\hline RS1 & $100 \%$ & & & & \\
RS2 & $80 \%$ & $100 \%$ & & & \\
RS3 & $82 \%$ & $80 \%$ & $100 \%$ & & \\
RS4 & $79 \%$ & $86 \%$ & $79 \%$ & $100 \%$ & \\
Bark & $87 \%$ & $76 \%$ & $81 \%$ & $76 \%$ & $100 \%$ \\
\hline
\end{tabular}

Table 5. Similarity matrix based on the SCOT analysis of the five tomato genotypes.

\begin{tabular}{cccccc}
\hline & RS1 & RS2 & RS3 & RS4 & Bark \\
\hline RS1 & $100 \%$ & & & & \\
RS2 & $78 \%$ & $100 \%$ & & & \\
RS3 & $80 \%$ & $80 \%$ & $100 \%$ & $100 \%$ & \\
RS4 & $75 \%$ & $87 \%$ & $77 \%$ & $76 \%$ & $100 \%$ \\
Bark & $82 \%$ & $78 \%$ & $79 \%$ & & \\
\hline
\end{tabular}

\subsection{Plant Growth}

The self-grafted Bark exhibited a gradual decrease in shoot fresh weight reaching about $43 \%$ of the corresponding unstressed control following the application of $50 \%$ of the normal water supply (Figure 2a). Although similar behavior was recorded for shoots 
grafted on the remaining rootstocks, heterografts exhibited enhanced shoot fresh weight under all growth conditions. The drought-mitigatory effect of grafting on the rootstock of different genotypes was more evident regarding shoot dry weight (Figure 2b). Compared with unstressed, the Bark self-grafted, shoot dry weight remained without significant change on the remaining rootstocks under all drought treatments.

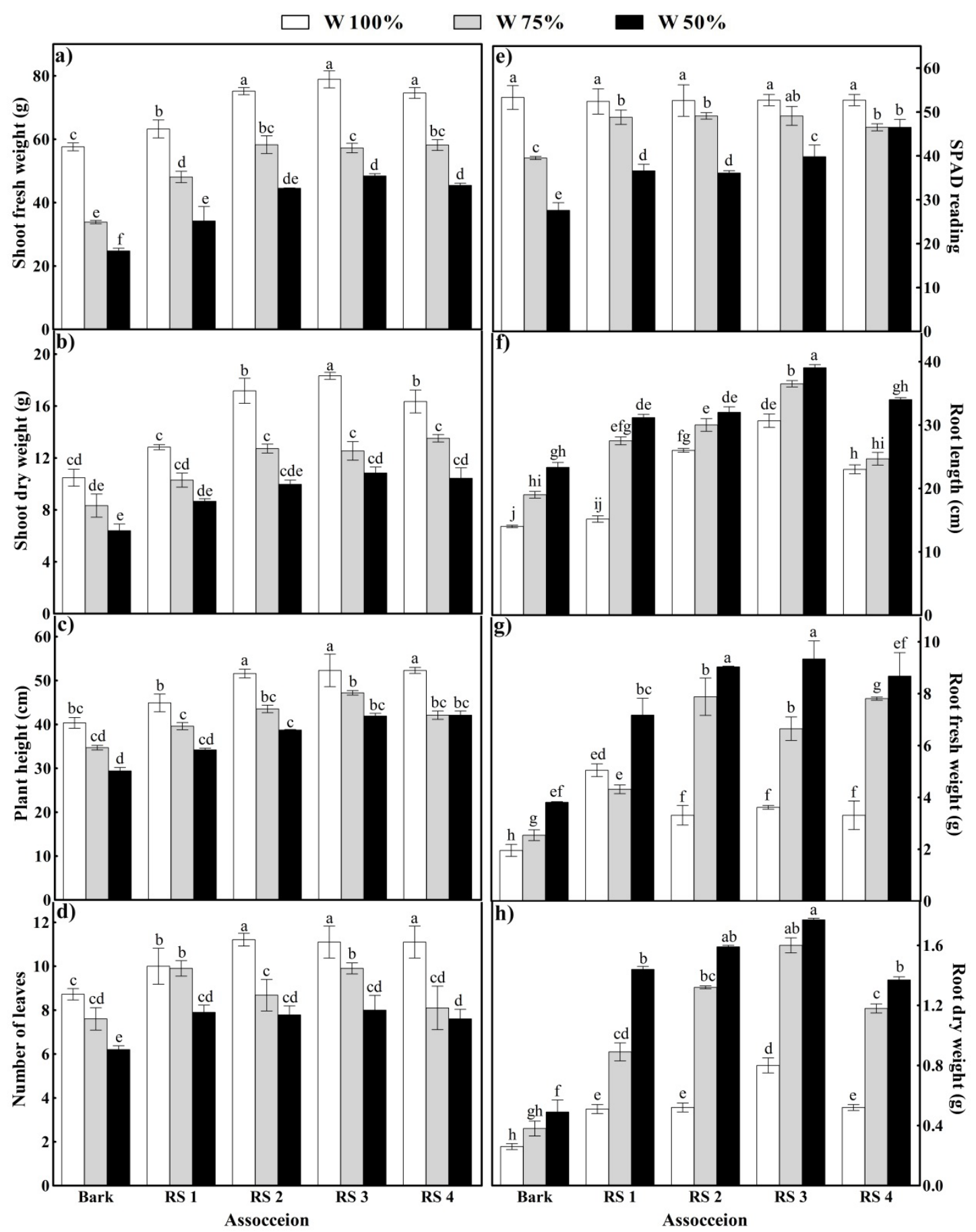

Figure 2. Effect of interaction between drought treatments and rootstock on (a) shoot fresh weight, (b) shoot dry weight, (c) plant height, (d) number of leaves, (e) SPAD reading, (f) root length, (g) root fresh weight, and (h) root dry weight. Different letters indicate significant differences between treatments (Tukey test at $p<0.05$ ). 
Given the recommended water requirements, the Bark scion grafted on the rootstock of the same genotype reached about $40 \mathrm{~cm}$ in height (Figure 2c). Replacing the Bark rootstock with either RS2-RS4 was associated with about 15\% increase in shoot height that remained without significant change on RS1. Applying 75\% of the normal water requirement did not affect the length of shoots grafted on the Bark rootstock while it was associated with a 10 to $20 \%$ decrease on the other rootstocks, regarding the normally hydrated corresponding control of each grafting combination. Shoot lengths remained insignificantly changed following a further decrease in the water supply to $50 \%$ of normal needs. Compared with shoot length recorded for self-graft combination growing under well-watered conditions, grafting on other rootstocks completely nullified the growth retarding effect of all drought treatments.

Under normal irrigation, grafting on RS1-RS4 improved the number of leaves, compared with self-graft combination; that was less obvious utilizing RS1 (Figure 2d). Reducing water of irrigation to $75 \%$ of the recommended water demands did not alter leaf number for self-graft combination. A similar result was observed utilizing RS1. Otherwise, both drought treatments were accompanied by a significant 11 to $32 \%$ decrease in the number of leaves, compared with the corresponding control, which was more pronounced on RS1 applying 50\% of the recommended water requirements. Grafting on RS1-RS4 had an alleviatory drought effect on the number of leaves. Under drought stress conditions, the number of leaves of all graft unions remained comparable with that counted for self-graft combination growing under normal hydration conditions with one exception for plants grafted on RS4 which provided $50 \%$ of the recommended water requirements.

Rootstock did not affect chlorophyll content as indicated with SPAD readings under normal conditions (Figure 2e). Concerning readings recorded under drought-free circumstances for each grafting combination, dehydration was accompanied by a 7 to $26 \%$ decrease in chlorophyll content except for plants grafted on RS3 supplemented with 75\% of the recommended water needs. The deleterious effects of drought on chlorophyll were intensified reaching a 12 to $48 \%$ decrease given $50 \%$ of the normal water requirements.

The drought tolerance of RS1-RS4 appeared in better root growth than the Bark roots under the same conditions. Under normal hydration, root length reached about $14 \mathrm{~cm}$ for the Bark rootstock insignificantly different from that of RS1, while it reached 26, 30 and $23 \mathrm{~cm}$ in RS2, RS3 and RS4, respectively (Figure 2f). With one exception for RS4, root lengths increased significantly by 15 to $81 \%$ following application of $75 \%$ of normal water requirements and by 23 to $106 \%$ upon halving water of irrigation.

Regarding results recorded for the Bark rootstock given the recommended water regime, fresh weights of all roots of other rootstocks exhibited a 70 to $160 \%$ increase, under the same conditions (Figure 2g). Except for the fresh weight of RS1 supplied with 75\% of the normal water requirements, a decrease in water supply was accompanied by a gradual increase in root fresh weight reaching 1.4- to 2.7-fold increase of the corresponding unstressed control upon application of $50 \%$ of plant water requirements. Similarly, dry weights of all roots of RS1-RS4 reached a 1.8- to 3-fold increase of that recorded for the Bark rootstock under unstressed conditions (Figure 2h). Applying 75\% of water needs to the Bark roots resulted in the same dry weight recorded under normal hydration conditions while halving water supply resulted in an $88 \%$ increase in root dry weight. Compared with the corresponding unstressed control, applying $75 \%$ of the normal water requirements resulted in a 73 to $156 \%$ increase in root dry weight for all rootstocks, while giving half of the normal water needs was associated with a 1.2- to 2.1-fold increase in dry weights.

\subsection{Yield and Quality of Tomato Fruits}

The rootstock appeared to have no significant effect on the number of fruits under normal irrigation conditions (Figure 3a). Compared with the corresponding unstressed control, applying $75 \%$ of the normal water needs was accompanied by about a $15 \%$ decrease in the number of fruits on the Bark and RS2 while not affecting other rootstocks. 
Applying $50 \%$ of the recommended water reduced number of fruits reaching 58 to $80 \%$ of the corresponding control.

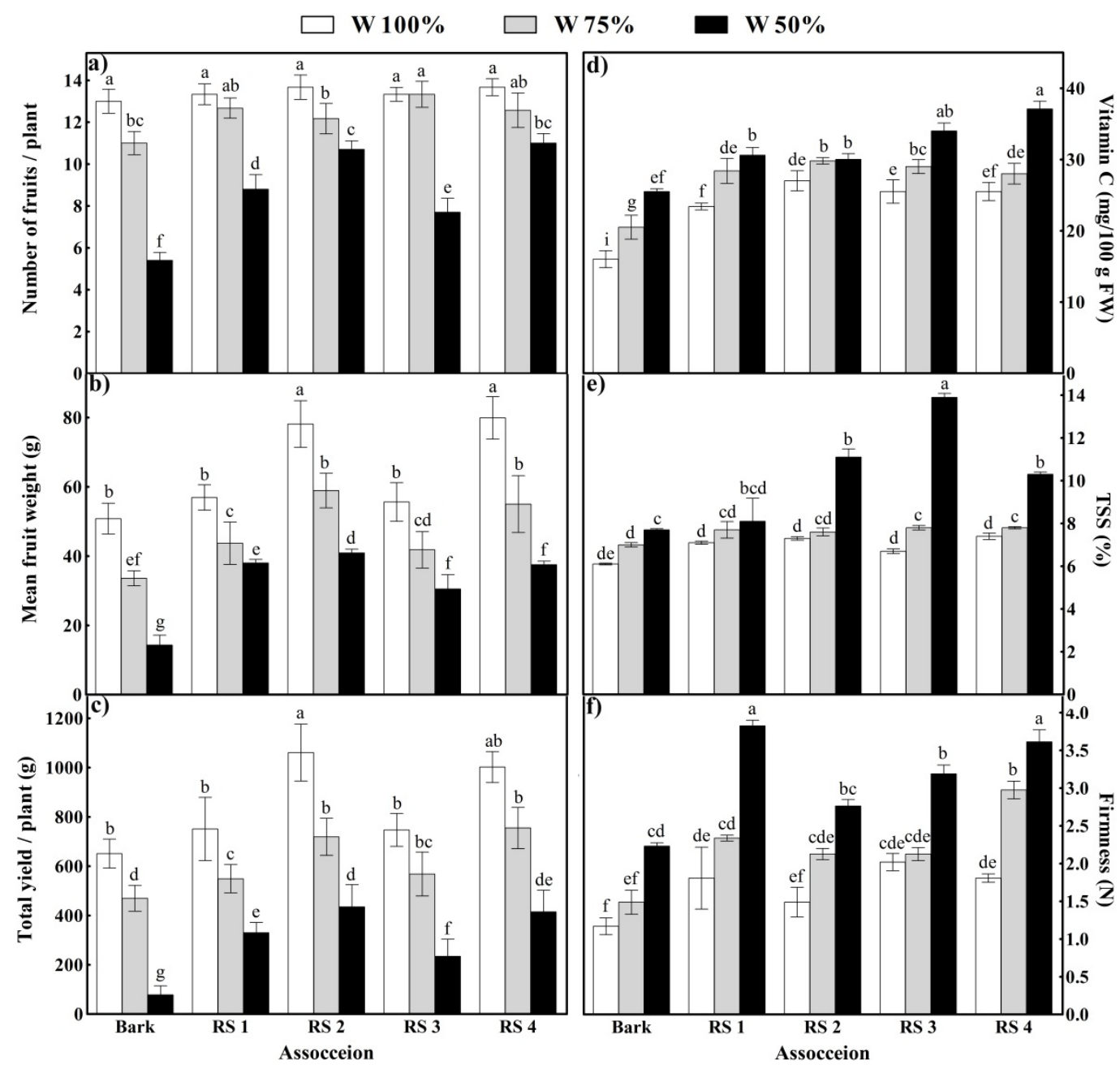

Figure 3. Effect of interaction between drought treatments and rootstock on (a) number of fruit/plant, (b) mean fruit weight, (c) total yield/plant, (d) vitamin C content, (e) TSS and (f) firmness. Different letters indicate significant differences between treatments (Tukey test at $p<0.05$ ).

The drought-ameliorating effect of grafting on RS1-RS4 appeared in higher average weight of fruit and total yield, compared with grafting on the Bark rootstock, under the same drought conditions. RS2 and RS4 appeared to be superior to other rootstocks concerning the average weight of fruit applying a normal water regime (Figure 3b). Decrease in the water of irrigation was associated with the gradual decrease in fruit weight reaching 47 to $67 \%$ of the corresponding control upon halving water supply. A more or less similar trend was assumed by total yield where RS2 and RS4 remained superior and drought treatments were accompanied by a decrease in total yield that was gradual in most cases (Figure 3c).

Regarding vit $\mathrm{C}$ content in fruits on the Bark rootstock, grafting on the other rootstocks significantly improved this yield quality parameter under all growth conditions. Compared with the corresponding unstressed control, application of $75 \%$ of the recommended water supply induced a 10 to $28 \%$ increase in vit C content of fruits on all rootstocks except those on RS4 that remained insignificantly affected (Figure 3d). Further increase in dehydration severity was associated with a further significant increase in Vit C content of fruits on RS1 and RS4 in addition to the Bark rootstock.

The rootstock genotype did not influence the TSS content of fruit under drought-free conditions (Figure 3e). Both drought treatments did not enhance TSS content for fruits 
on RS1. At 75\% of normal hydration, TSS content increased reaching 105 to $115 \%$ of the corresponding normally irrigated control for fruits on RS3 and RS4, while it remained insignificantly affected on RS2 and the Bark rootstock. TSS content reached about 1.39- to 2.1-fold of control for fruits on RS2-RS4 while reached about 1.25-fold of control on the Bark rootstock in response to applying $50 \%$ of normal water supply.

Under normal irrigation conditions, fruit firmness on RS1, RS3 or RS4 was significantly higher than that recorded for fruits on the Bark rootstock (Figure 3f). However, replacing the Bark rootstock with RS2 had no significant effect on fruit firmness under all growth conditions. Applying 75\% of the normal water demands enhanced fruit firmness on RS4 reaching 1.7-fold of the corresponding control while it had no significant effect utilizing the remaining rootstocks. Additional reduction in the water supply to $50 \%$ of normal needs was accompanied by an increase in fruit firmness on all rootstocks that were more obvious on RS1, RS3 and RS4, compared with the Bark rootstock.

\subsection{Mineral Content in Tomato Shoots}

Compared with the corresponding control receiving the normal water regime, drought treatments were accompanied by a decrease in mineral content in plants grafted on the Bark rootstock except potassium content applying $75 \%$ of the normal water requirements (Table 6).

Table 6. Effect of interaction between drought treatments and rootstock on the minerals content of the tomato shoots.

\begin{tabular}{|c|c|c|c|c|c|c|}
\hline \multirow{2}{*}{ Mineral } & \multirow{2}{*}{ Treatment } & \multicolumn{5}{|c|}{ Rootstock } \\
\hline & & Bark & RS1 & RS2 & RS3 & RS4 \\
\hline \multirow{3}{*}{ N (\%) } & W100\% & $3.06 \mathrm{~b}$ & $3.67 \mathrm{a}$ & $2.99 \mathrm{~b}$ & $2.60 \mathrm{cb}$ & $3.10 \mathrm{~b}$ \\
\hline & W 75\% & $2.19 \mathrm{c}$ & $2.52 \mathrm{cb}$ & $2.51 \mathrm{cb}$ & $2.18 \mathrm{c}$ & $2.59 \mathrm{cb}$ \\
\hline & W50\% & $1.18 \mathrm{~g}$ & $1.83 \mathrm{de}$ & $1.50 \mathrm{f}$ & $1.88 \mathrm{e}$ & $2.01 \mathrm{~d}$ \\
\hline \multirow{3}{*}{ P (\%) } & W100\% & $0.22 \mathrm{ef}$ & $0.37 \mathrm{a}$ & $0.35 \mathrm{ab}$ & $0.30 \mathrm{cb}$ & $0.25 \mathrm{ed}$ \\
\hline & W 75\% & $0.15 \mathrm{~g}$ & $0.25 \mathrm{de}$ & $0.29 \mathrm{cb}$ & $0.25 \mathrm{de}$ & $0.29 \mathrm{cb}$ \\
\hline & W50\% & $0.12 \mathrm{~h}$ & $0.22 \mathrm{ef}$ & 0.23 ef & 0.23 ef & 0.22 ef \\
\hline \multirow{3}{*}{ K (\%) } & W100\% & $2.62 \mathrm{ef}$ & $4.25 \mathrm{a}$ & $3.66 \mathrm{~b}$ & $3.55 \mathrm{~b}$ & $4.14 \mathrm{a}$ \\
\hline & W 75\% & $2.21 \mathrm{fg}$ & $3.41 \mathrm{bcd}$ & $3.30 \mathrm{~cd}$ & $3.03 \mathrm{de}$ & $3.65 \mathrm{~b}$ \\
\hline & W50\% & $1.88 \mathrm{~g}$ & 2.69 de & $2.86 \mathrm{de}$ & $2.40 \mathrm{efg}$ & $3.63 \mathrm{~b}$ \\
\hline \multirow{3}{*}{$\mathrm{Ca}(\%)$} & $\mathrm{W} 100 \%$ & $0.65 \mathrm{de}$ & $1.29 \mathrm{a}$ & $0.79 \mathrm{bc}$ & $0.76 \mathrm{bc}$ & $0.81 \mathrm{~b}$ \\
\hline & W 75\% & $0.41 \mathrm{~g}$ & $0.72 \mathrm{~d}$ & 0.66 de & $0.51 \mathrm{fg}$ & $0.67 \mathrm{de}$ \\
\hline & W50\% & $0.29 \mathrm{~h}$ & $0.49 \mathrm{~g}$ & $0.55 \mathrm{f}$ & $0.54 \mathrm{f}$ & 0.60 ef \\
\hline \multirow{3}{*}{$\operatorname{Mg}(\%)$} & $\mathrm{W} 100 \%$ & $0.30 \mathrm{gh}$ & $0.50 \mathrm{~b}$ & $0.53 \mathrm{a}$ & $0.35 \mathrm{dc}$ & 0.33 def \\
\hline & W 75\% & $0.22 \mathrm{f}$ & $0.39 \mathrm{cb}$ & 0.36 cde & 0.33 def & 0.34 def \\
\hline & W50\% & $0.17 \mathrm{j}$ & $0.21 \mathrm{f}$ & 0.30 ef & $0.22 \mathrm{f}$ & 0.29 ef \\
\hline \multirow{3}{*}{$\mathrm{Fe}(\mathrm{ppm})$} & W100\% & $47.49 \mathrm{fg}$ & $79.40 \mathrm{a}$ & 57.34 cde & $64.71 \mathrm{~b}$ & $62.42 \mathrm{bc}$ \\
\hline & W 75\% & $40.26 \mathrm{~h}$ & $52.21 \mathrm{efg}$ & $52.19 \mathrm{efg}$ & 57.27 cde & 53.74 ef \\
\hline & $\mathrm{W} 50 \%$ & $38.00 \mathrm{i}$ & $55.34 \mathrm{de}$ & $52.80 \mathrm{efg}$ & $54.65 \mathrm{de}$ & $56.23 \mathrm{de}$ \\
\hline
\end{tabular}

Different letters indicate significant differences between treatments (Tukey test at $p<0.05$ ).

Compared with the corresponding unstressed control, a general decrease in mineral content was estimated in plants grafted on the other rootstocks under drought treatments with genotype-dependent exceptions. On RS1, an insignificant change was recorded for magnesium giving 75\% of the normal water supply. Grafting on RS2 was associated with an insignificant change in nitrogen and phosphorus content giving $75 \%$ of the normal water supply and in iron applying all drought treatments. Concerning RS3, insignificant changes were observed for nitrogen and magnesium following a $25 \%$ decrease in water needs. For RS4, the insignificant changes included nitrogen applying $75 \%$ of water needs and phosphorous applying 50\% of water requirements; in addition to magnesium under all drought conditions. 
Under water stress-free conditions, replacing the Bark rootstock with RS1 significantly enhanced the accumulation of all minerals. More or less similar results were recognized using the remaining rootstocks except for the insignificant changes recorded in nitrogen content on all rootstocks and phosphorous content on RS4. The enhanced mineral accumulation on RS1-RS4 compared with the Bark rootstock was also recorded during drought treatments with some exceptions. Applying $75 \%$ of the normal water requirements nullified the effect of rootstock genotype on nitrogen content. In the same treatment, calcium content on RS3 and magnesium content on RS3 and RS4 were comparable with corresponding results recorded on the Bark rootstock. Halving water supply was accompanied by comparable results for potassium on RS3 and those estimated on the Bark rootstock.

\subsection{Plant Hormones and Antioxidant Enzymes in Tomato Shoots}

$\mathrm{GA}_{3}$ content in plants grafted on the Bark rootstock reached $72 \mu \mathrm{g} \mathrm{g}^{-1}$, on a fresh weight basis under normal hydration conditions (Figure 4a). Replacing the Bark rootstock with RS1 was accompanied by a $62 \%$ significant increase in $\mathrm{GA}_{3}$ that was absent on the remaining rootstocks. A decrease in water supply was associated with a gradual decrease in $\mathrm{GA}_{3}$ content in plants grafted on the Bark rootstock in addition to RS1 and RS2, compared with the corresponding normally irrigated control. On the other hand, a decrease in the hormone for plants grafted on RS3 and RS4 was only observed upon halving the water supply.

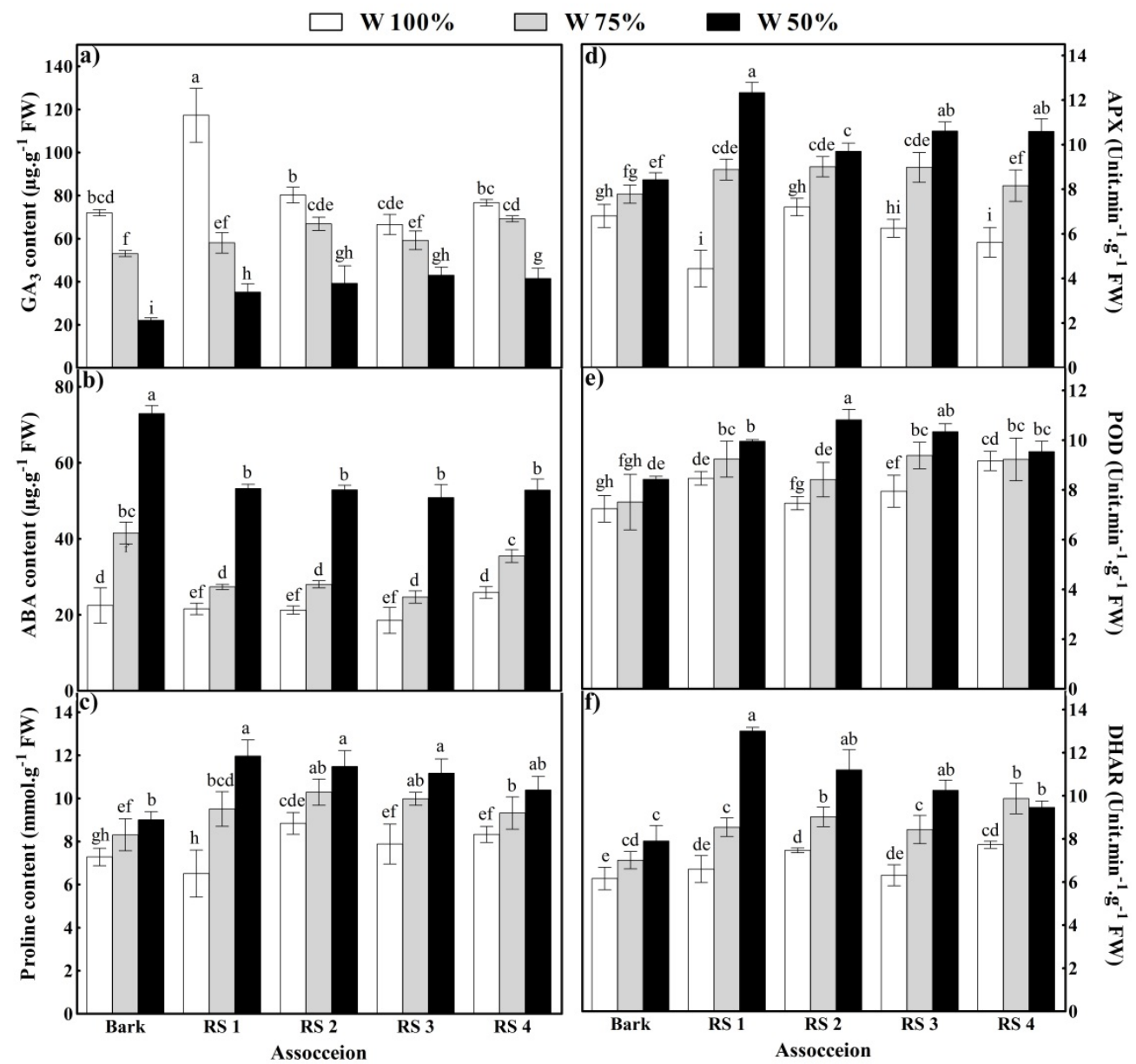

Figure 4. Effect of interaction between drought treatments and rootstock on (a) $\mathrm{GA}_{3},(\mathbf{b}) \mathrm{ABA}$, (c) proline, (d) APX, (e) POD and (f) DHAR. Different letters indicate significant differences between treatments (Tukey test at $p<0.05$ ). 
Applying 75\% of the recommended requirements, grafting on RS1-RS4 had a drought culminating effect on $\mathrm{GA}_{3}$ content that remained comparable with that estimated for self-graft combination given the normal hydration.

Applying $100 \%$ or $75 \%$ of the normal water requirements, ABA content in shoots grafted on RS4 and the Bark rootstock was insignificantly different (Figure 4b). Otherwise, shoots grafted on the Bark rootstock accumulated higher ABA amounts than those grafted on other rootstocks under the same growth conditions. The stress hormone gradually decreased in response to a decrease in water supply for shoots grafted on all rootstocks.

Under normal hydration conditions, proline accumulation in shoots grafted on RS1 and the Bark rootstock was comparable, while higher proline content was estimated on the remaining rootstocks (Figure 4c). However, after applying drought treatments, proline content was higher in plants grafted on RS1-RS4 than those grafted on the Bark rootstock. Regarding the corresponding unstressed control, reducing water supply was associated with a gradual increase in proline accumulation in plants grafted on the Bark rootstock and RS1. On the other hand, both drought treatments had the same significant promoting effect on proline accumulation for plants grafted on the remaining rootstocks.

Grafting on genetically different rootstocks provoked the addressed antioxidant enzymes under normal hydration conditions with few exceptions (Figure 4d-f). For APX, comparable activities for APX were recorded in plants grafted on the Bark rootstock and RS2. The same exception was detected for POD. Concerning DHAR, insignificantly different activities were assayed in plants grafted on the Bark rootstock, RS1 and RS3. The stimulatory effect of grafting on the rootstock of different genotypes was also observed under drought conditions with exceptions restricted to plants supplied with $75 \%$ of the normal water requirements. Similar APX activities were estimated in plants grafted on the Bark rootstock and RS4 in addition to similar DHAR activities which were recorded in plants grafted on the Bark rootstock, RS1 and RS3.

Compared with the corresponding unstressed control, DHAR activity increased gradually in response to a decrease in water supply in plants grafted on the Bark rootstock (Figure $4 \mathrm{f}$ ). Concerning the remaining enzymes, the enhanced activities were restricted to halving the water supply (Figure $4 \mathrm{~d}, \mathrm{e}$ ). On the other hand, plants grafted on the remaining rootstocks showed enhanced APX, POD, and DHAR activities in response to drought stress treatments except for POD in plants grafted on RS4.

\subsection{Clustering Analysis}

Figure 5 illustrates a heatmap showing the relationships among the rootstocks based on the phenotypic, physiological, and agronomical criteria. In this heatmap, the Bark and RS1 were clustered in one clade while the remaining rootstocks were clustered in another clade with fine resolution showing RS3 as an outgroup for a clade containing RS2 and RS4. 


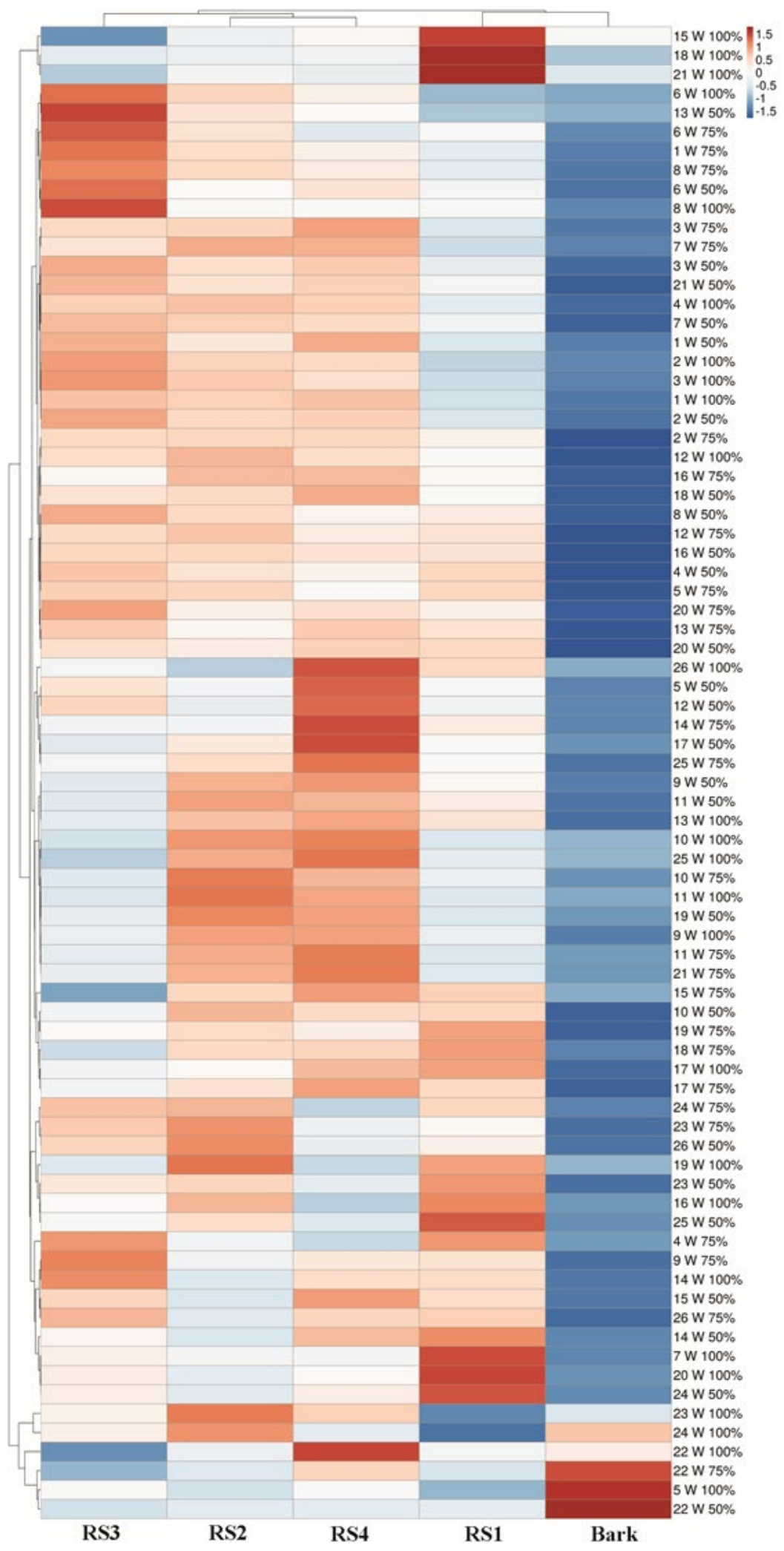

Figure 5. Heat map depicting clustering of tomato rootstocks based on: shoot fresh weight (1), shoot dry weight (2), shoot length (3), number of leaves (4), SPAD reading (5), root length (6), root fresh weight (7), root dry weight (8), number of fruit/plant (9), mean fruit weight (10), total yield/plant (11), vitamin C content (12), TSS (13), firmness (14), N (15), P (16), K (17), Ca (18), Mg (19), Fe (20), $\mathrm{GA}_{3}$ (21), ABA (22), proline (23), APX (24), DHAR (25), and POD (26) under different water regimes. 


\section{Discussion}

To our knowledge, it is the first time SCOT and CDDP markers were recruited to characterize the genetic relatedness among some tomato accessions in relation to their drought tolerance. Our results reflected that SCOT and CDDP systems as potent markers can successfully differentiate between the five tomato genotypes with superiority of ScoT over CDDP. Our results exhibited that ScoT successfully characterized $44 \%$ polymorphism while CDDP detected only $28 \%$ polymorphism among the addressed genotypes. The higher polymorphism recorded upon utilizing SCOT may be attributed to the abundance of binding sites targeted by its primers, compared with CDDP which was restricted to conserved regions within certain gene families. In agreement with our results, the superiority of SCoT over CDDP in the estimation of genetic polymorphism was recorded in previous work on tomato plants [37].

Results of the present investigation reflected the higher precision of CDDP in the characterization of genetic relatedness, compared with SCOT, concerning performance under drought stress. The CDDP revealed the same grouping pattern for genotypes that appeared in the heatmap that was established using phenotypic, physiological, and agronomical criteria under water-deficient conditions. The high precision may be associated with the dependence of CDDP on conserved regions of gene families involved in response to different types of stresses. Supporting this point of view, the highest polymorphism in CDDP markers was estimated using CDDP-4 targeting MYB genes implicated in secondary metabolism, abiotic and biotic stresses, and cellular morphogenesis. Compared with SCoTbased clustering, CDDP-based grouping showed higher agreement based on phenotypic, physiological, and agronomic performance recorded in grafted tomato plants exposed to salinity stress [37].

Results of the present investigation reflected a decline in shoot growth and total yield on one hand and enhancement of root growth and yield quality on the other hand, in response to drought stress for all grafted plants regardless of rootstock genotype. The contradictory influence of drought on the shoot and root growth can be attributed to the increase in ABA accumulation [38] manifested in our results in response to decreased soil hydration. The enhancement in root growth can be attributed to the positive modulation played by ABA on auxin signaling and transport [39]. On the other hand, growth retardation recorded for the shoots can be related to our results' synchronized decrease in $\mathrm{GA}_{3}$. GA 3 promotes major developmental processes including shoot elongation, leaf expansion, flowering and fruit development [40]. The decrease in $\mathrm{GA}_{3}$ in response to drought stress was related to antagonism with the accumulated ABA [41] and overexpression of the dehydration responsive element binding (DREB) family [42]. The increase in ABA content accompanied with retarded shoot growth in response to drought was documented in tomato seedlings grafted on drought tolerant rootstock by Zhang et al. [43]. In addition, Shohat et al. [44] documented the antagonistic relationship between $\mathrm{ABA}$ and $\mathrm{GA}_{3}$ in tomato seedlings subjected to water stress. Moreover, Ünyayar et al. [45] recorded the involvement of ABA in root development of tomato plants exposed to drought stress.

Stomatal closure is a well-known strategy to reduce water loss under drought conditions, but it concomitantly limits the entrance of carbon dioxide and subsequently impairs photosynthesis and enhances ROS production [46]. The accumulated ROS injures cellular macromolecules [47] and is responsible for the decrease in chlorophyll content demonstrated in the current study in response to drought stress. The deleterious effect of drought stress on the photosynthetic pigment was recorded in tomato plants by several research groups including Liang et al. [48] and Medyouni et al. [49].

In addition to a decrease in chlorophyll content, drought is associated with inhibition of electron flow in PSI [50], reduction in several Calvin cycle proteins, including Rubisco [51], and a decline in $\mathrm{CO}_{2}$ conductance due to stomatal closure [52] that finally impairs photosynthate accumulation and is expressed in the current study as a decrease in total yield. In agreement with our results, a decrease in tomato total yield in response to drought stress was recorded by Cui et al. [53]. 
Adding to the hormone-mediated effects of drought on growth and yield, the current results reflected the deleterious effect of water stress on mineral accumulation. Macro- and microelements are essential for normal growth and yield being fundamental components of vital biological macromolecules recruited in all physiological processes [54,55]. Reduction in the content of macroelements in grafted tomato was also estimated by Zhang et al. [14] in response to drought stress. In the same context, Kiran et al. [56] recorded the negative impact of water stress on potassium, calcium, iron, and zinc content in seedlings of four tomato genotypes. A decrease in mineral accumulation is explained by a reduction in nutrient diffusivity [57] and nutrient-uptake proteins in roots [58] in dry soils.

Fruit quality is a major concern for both growers and consumers. In this study, drought stress enhanced fruit firmness and the accumulation of total soluble solids and vit C. An increase in fruit firmness linked to the increase in soil water deficit may be associated with a decrease in water loss by increasing cuticle thickness [59]. In accordance with the present results, Sivakumar et al. [60] recorded an increase in fruit firmness in tomato plants growing under a water deficit. The same result was reported by Cui et al. [53] for tomato plants that experienced drought stress during the fruit ripening stage.

Decrease in soil hydration provokes defense mechanisms that decrease water potential of the cytosol to enhance water uptake efficiency through the accumulation of osmolytes, and scavenge the generated ROS through activation of enzymatic non-enzymatic antioxidants. ABA addressed in this study plays a major role in the elicitation of these mechanisms under conditions of abiotic stress. It mediates accumulation of osmolytes including proline and soluble sugars in tomato plants growing in dehydrated soils [61]. In addition, several research groups documented the role of ABA in the stimulation of non-enzymatic antioxidants including vit C [62] and ROS scavenging enzymes [63] in tomato plants subjected to water stress. These mechanisms add to fruit quality via increasing TSS and enhancing antioxidant accumulation including vit $\mathrm{C}$ as recorded in the current results. The current enhancement in TSS and vit C content in tomato fruits growing under drought stress conditions was also estimated by Dariva et al. [59].

In agreement with our results, enhanced proline accumulation was recorded in tomato plants as a response to water deficit [11]. Besides the role played as an osmolyte, proline acts as an antioxidative defense molecule and a metal chelator. Furthermore, proline is a proteinogenic amino acid with the $\alpha$-amino group present as an auxiliary amine which is essential for primary metabolism $[64,65]$.

The current study reflected an increase in the activity of the addressed ROS scavenging enzymes including APX, POD, and DHAR in response to drought stress. The first two enzymes share in the detoxification of $\mathrm{H}_{2} \mathrm{O}_{2}$. APX catalyzes the transformation of $\mathrm{H}_{2} \mathrm{O}_{2}$ into $\mathrm{H}_{2} \mathrm{O}$, using ascorbate as an electron donor, and is upregulated in response to drought stress [66]. POD scavenges $\mathrm{H}_{2} \mathrm{O}_{2}$, produced through dismutation of $\mathrm{O}_{2}{ }^{-}$catalyzed by superoxide dismutase, with a synchronized oxidation of a substrate, mostly located in the cell wall [67]. The increase in activity of these $\mathrm{H}_{2} \mathrm{O}_{2}$ scavenging enzymes is a common response observed in tomato plants suffering from water shortage [68,69]. DHAR directly regenerates ascorbic acid from its oxidized state sharing in the metabolic recycling of vit $\mathrm{C}$ which is known to be one of the most abundant antioxidants in the cell [70]. In accordance with the current results, Murshed et al. [71] recorded an increase in DHAR activity in tomato plants experiencing drought stress. Conversely, Raja et al. [72] recorded the negative impact of water stress on tomato DHAR. Working on five tomato genotypes, Yao et al. [73] documented the genotype dependence of DHAR response against drought stress.

The current results reflected the agronomic superiority of the Bark grafted on genetically different rootstocks over the Bark autografts under drought conditions. Such superiority was clearly related to more efficient defense mechanisms including extensive root growth and accumulation of compatible osmolytes and antioxidants established on RS1-RS4, compared with the Bark rootstock. Supporting these results, Zhang et al. [15] recorded drought attenuating effects of grafting on tomato drought-tolerant rootstocks, compared with grafting on sensitive rootstocks, where shoots exploited the extensive 
growth of the tolerant rootstock and developed higher activities for antioxidant enzymes including superoxide dismutase, catalase, and peroxidase to remove the accumulated ROS. The advantageous effect of grafting on drought-tolerant rootstocks of tomato plants was also documented by Yao et al. [73]. The authors attributed enhancement in drought tolerance to enhancements in POD, APX, and DHAR activities and proline accumulation. In the same context, Sánchez-Rodríguez et al. [74-76] recorded the accumulation of higher amounts of ascorbic acid in tomato fruits produced by shoots grafted on tolerant rootstocks.

Application of grafting for reducing drought stress is of course connected with increased costs. In this study, the application of grafting lead to an additional cost of $6.5 \%$ of the total cost per hectare. However, considering the economic consequences caused by drought stress, these costs should be regarded as marginal.

\section{Conclusions}

Our results revealed the harmony between genetic relatedness among the utilized rootstocks, as indicated by SCOT and CDDP. The relations appeared in the heatmap, constructed based on phenotypic, physiological, and agronomical performance of graft unions between each of these rootstocks and the drought-sensitive genotype (Bark). All relations reflected the grouping of the Bark and RS1 on one hand and clustering of the remaining rootstocks on the other hand with fine resolution showing RS3 as an outgroup for a clade containing RS2 and RS4. These results support the utilization of SCoT and CDDP as a powerful screening tool useful in predicting the physiological and agronomical behavior of grafting on different tomato rootstocks. According to our cost-benefit analysis, we could use the grafting on the previous resistant phenotypes under drought stress $(75 \%$ of recommended rate) with higher net profit than normal conditions. Furthermore, grafting could be an alternative cost-efficient method in improving drought tolerance among sensitive tomato genotypes.

Supplementary Materials: The following supporting information can be downloaded at: https: / / www.mdpi.com/article/10.3390/agronomy12010153/s1, Table S1: Description of used tomato accessions according to International Tomato Genetic Resources Centre at USA.

Author Contributions: Conceptualization, M.A.M.A., A.S.F. and E.A.A.; methodology, M.A.M.A., A.S.F., E.A.A. and M.M.E.-M.; software, M.A.M.A., A.S.F., E.A.A., E.S.A.B. and F.D.; validation, M.A.M.A., M.M.E.-M., E.A.A. and A.S.F.; formal analysis, M.A.M.A., E.A.A. and K.F.A.; investigation, M.A.M.A., A.S.F., M.M.E.-M., E.A.A., M.F.M.I.; resources, M.A.M.A. and E.A.A.; data curation, A.S.F., E.K., E.A.A., M.F.M.I. and B.N.S.; writing-original draft preparation, M.A.M.A., A.S.F., M.M.E.-M. and E.A.A.; writing-review and editing, M.A.M.A., A.S.F., M.M.E.-M., M.F.M.I., E.A.A. and K.F.A.; visualization, M.A.M.A., E.A.A., A.S.F. and K.F.A.; supervision, M.A.M.A., M.M.E.-M. and E.A.A.; project administration, M.A.M.A., M.M.E.-M. and E.A.A.; funding acquisition, E.K., E.A.A., E.S.A.B. and F.D. All authors have read and agreed to the published version of the manuscript.

Funding: This research received no external funding.

Data Availability Statement: Data sharing is not applicable to this article.

Acknowledgments: Authors would like to appreciate Cairo University, Faculty of Agriculture for providing the facilities to carry out this research work. Also, the authors would like to sincerely thank the administration of the Agricultural Genetic Engineering Research Institute (AGERI), Agricultural Research Center (ARC), Egypt, to facilitate the carrying out of whole molecular analysis experiments. Additionally, the authors extend their appreciation to Taif University for funding current work by Taif University Researchers Supporting Project number (TURSP-2020/307), Taif University, Taif, Saudi Arabia.

Conflicts of Interest: The authors declare no conflict of interest. 


\section{References}

1. Ballon-Landa, E.; Parsons, J.K. Nutrition, Physical Activity, and Lifestyle Factors in Prostate Cancer Prevention. Curr. Opin. Urol. 2018, 28, 55-61. [CrossRef] [PubMed]

2. Kapoor, D.; Bhardwaj, S.; Landi, M.; Sharma, A.; Ramakrishnan, M.; Sharma, A. The Impact of Drought in Plant Metabolism: How to Exploit Tolerance Mechanisms to Increase Crop Production. Appl. Sci. 2020, 10, 5692. [CrossRef]

3. Abbasi, T.; Abbasi, S. Biomass Energy and the Environmental Impacts Associated with Its Production and Utilization. Renew. Sustain. Energy Rev. 2010, 14, 919-937. [CrossRef]

4. Brodersen, C.R.; Roddy, A.B.; Wason, J.W.; McElrone, A.J. Functional Status of Xylem through Time. Annu. Rev. Plant Biol. 2019, 70, 407-433. [CrossRef] [PubMed]

5. Seleiman, M.F.; Al-Suhaibani, N.; Ali, N.; Akmal, M.; Alotaibi, M.; Refay, Y.; Dindaroglu, T.; Abdul-Wajid, H.H.; Battaglia, M.L. Drought Stress Impacts on Plants and Different Approaches to Alleviate Its Adverse Effects. Plants 2021, 10, 259. [CrossRef]

6. Food and Agriculture Organization. Future of Food and Agriculture 2018: Alternative Pathways to 2050; Food and Agriculture Organization: Rome, Italy, 2018.

7. Kumawat, K.R.; Sharma, N. Effect of Drought Stress on Plants Growth. Pop. Kheti 2018, 6, $239-241$.

8. Sharma, A.; Kumar, V.; Shahzad, B.; Ramakrishnan, M.; Singh Sidhu, G.P.; Bali, A.S.; Handa, N.; Kapoor, D.; Yadav, P.; Khanna, K.; et al. Photosynthetic Response of Plants under Different Abiotic Stresses: A Review. J. Plant Growth Regul. 2020, 39, 509-531. [CrossRef]

9. Ibrahim, M.F.; Elbar, O.H.A.; Farag, R.; Hikal, M.; El-Kelish, A.; El-Yazied, A.A.; Alkahtani, J.; El-Gawad, H.G.A. Melatonin Counteracts Drought Induced Oxidative Damage and Stimulates Growth, Productivity and Fruit Quality Properties of Tomato Plants. Plants 2020, 9, 1276. [CrossRef] [PubMed]

10. Fathi, A.; Tari, D.B. Effect of Drought Stress and Its Mechanism in Plants. Int. J. Life Sci. 2016, 10, 1-6. [CrossRef]

11. Ibrahim, M.F.; El-Samad, A.; Ashour, H.; El-Sawy, A.M.; Hikal, M.; Elkelish, A.; El-Gawad, H.A.; El-Yazied, A.A.; Hozzein, W.N.; Farag, R.; et al. Regulation of Agronomic Traits, Nutrient Uptake, Osmolytes and Antioxidants of Maize as Influenced by Exogenous Potassium Silicate under Deficit Irrigation and Semiarid Conditions. Agronomy 2020, 10, 1212. [CrossRef]

12. Salehi-Lisar, S.Y.; Bakhshayeshan-Agdam, H. Drought stress in plants: Causes, consequences, and tolerance. In Drought Stress Tolerance in Plants; Springer: Berlin/Heidelberg, Germany, 2016; Volume 1, pp. 1-16.

13. Singh, H.; Kumar, P.; Chaudhari, S.; Edelstein, M. Tomato Grafting: A Global Perspective. HortScience 2017, 52, 1328-1336. [CrossRef]

14. Zhang, Z.; Liu, Y.; Cao, B.; Chen, Z.; Xu, K. The Effectiveness of Grafting to Improve Drought Tolerance in Tomato. Plant Growth Regul. 2020, 91, 157-167. [CrossRef]

15. Zhang, Z.; Cao, B.; Gao, S.; Xu, K. Grafting Improves Tomato Drought Tolerance through Enhancing Photosynthetic Capacity and Reducing ROS Accumulation. Protoplasma 2019, 256, 1013-1024. [CrossRef]

16. Aguilera, J.G.; Pessoni, L.A.; Rodrigues, G.B.; Elsayed, A.Y.; Da Silva, D.J.; De Barros, E.G. Genetic Variability by ISSR Markers in Tomato (Solanum Lycopersicon Mill.). Rev. Bras. Ciências Agrárias 2011, 6, 243-252. [CrossRef]

17. Robinson, J.P.; Harris, S.A. Amplified Fragment Length Polymorphism and Microsatellites: A phylogenetic perspective. In Proceedings of the in Which DNA Marker for Which Purpose? Final Compendium of the Research Project Development, Optimisation and Validation of Stephen P. DiFazio; Citeseer: State College, PA, USA, 1999.

18. Osuna-Martínez, U.; Reyes-Esparza, J.; Rodríguez-Fragoso, L. Cactus (Opuntia Ficus-Indica): A Review on Its Antioxidants Properties and Potential Pharmacological Use in Chronic Diseases. Nat. Prod. Chem. Res. 2014, 2, 153.

19. Atia, M.A.; Abdeldaym, E.A.; Abdelsattar, M.; Ibrahim, D.S.; Saleh, I.; Abd Elwahab, M.; Osman, G.H.; Arif, I.A.; Abdelaziz, M.E Piriformospora Indica Promotes Cucumber Tolerance against Root-Knot Nematode by Modulating Photosynthesis and Innate Responsive Genes. Saudi J. Biol. Sci. 2020, 27, 279-287. [CrossRef]

20. Collard, B.; Mackill, D. Conserved DNA-Derived Polymorphism (CDDP): A Simple and Novel Method for Generating DNA Markers in Plants. Plant Mol. Biol. Rep. 2009, 27, 558-562. [CrossRef]

21. Atia, M.A.; Sakr, M.M.; Mokhtar, M.M.; Adawy, S.S. Development of sex-specific PCR-based markers in date palm. In Date Palm Biotechnology Protocols Volume II; Springer: Berlin/Heidelberg, Germany, 2017; pp. 227-244.

22. Letunic, I.; Bork, P. Interactive Tree Of Life v2: Online Annotation and Display of Phylogenetic Trees Made Easy. Nucleic Acids Res. 2011, 39, W475-W478. [CrossRef]

23. Abouseadaa, H.H.; Atia, M.A.; Younis, I.Y.; Issa, M.Y.; Ashour, H.A.; Saleh, I.; Osman, G.H.; Arif, I.A.; Mohsen, E. Gene-Targeted Molecular Phylogeny, Phytochemical Profiling, and Antioxidant Activity of Nine Species Belonging to Family Cactaceae. Saudi J. Biol. Sci. 2020, 27, 1649-1658. [CrossRef]

24. Abdelgawad, K.F.; El-Mogy, M.M.; Mohamed, M.I.A.; Garchery, C.; Stevens, R.G. Increasing Ascorbic Acid Content and Salinity Tolerance of Cherry Tomato Plants by Suppressed Expression of the Ascorbate Oxidase Gene. Agronomy 2019, 9, 51. [CrossRef]

25. AOAC International. Official Methods of Analysis of the Association of Official Analytical Chemists; AOAC International: Rockville, MD, USA, 1925; Volume 2.

26. Piper, C.S. Soil and Plant Analysis; Scientific Publishers: Jodhpur, Rajasthan, 2017.

27. Bates, L.S.; Waldren, R.P.; Teare, I. Rapid Determination of Free Proline for Water-Stress Studies. Plant Soil 1973, 39, $205-207$. [CrossRef] 
28. Fales, H.; Jaouni, T.; Babashak, J. Simple Device for Preparing Ethereal Diazomethane without Resorting to Codistillation. Anal. Chem. 1973, 45, 2302-2303. [CrossRef]

29. Abdelaziz, M.; Abdeldaym, E. Effect of Grafting and Different Ec Levels of Saline Irrigation Water on Growth, Yield and Fruit Quality of Tomato (Lycopersicon Esculentum) in Greenhouse. Plant Arch. 2019, 19, 3021-3027.

30. Abdelaziz, M.E.; Abdelsattar, M.; Abdeldaym, E.A.; Atia, M.A.; Mahmoud, A.W.M.; Saad, M.M.; Hirt, H. Piriformospora Indica Alters $\mathrm{Na}^{+} / \mathrm{K}^{+}$Homeostasis, Antioxidant Enzymes and LeNHX1 Expression of Greenhouse Tomato Grown under Salt Stress. Sci. Hortic. 2019, 256, 108532. [CrossRef]

31. Wang, Q.; Zhao, R.; Chen, Q.; da Silva, J.A.T.; Chen, L.; Yu, X. Physiological and Biochemical Responses of Two Herbaceous Peony Cultivars to Drought Stress. HortScience 2019, 54, 492-498. [CrossRef]

32. García-Limones, C.; Hervás, A.; Navas-Cortés, J.A.; Jiménez-Díaz, R.M.; Tena, M. Induction of an Antioxidant Enzyme System and Other Oxidative Stress Markers Associated with Compatible and Incompatible Interactions between Chickpea (Cicer Arietinum L.) and Fusarium Oxysporum f. sp. Ciceris. Physiol. Mol. Plant Pathol. 2002, 61, 325-337. [CrossRef]

33. Baier, M.; Noctor, G.; Foyer, C.H.; Dietz, K.-J. Antisense Suppression of 2-Cysteine Peroxiredoxin in Arabidopsis Specifically Enhances the Activities and Expression of Enzymes Associated with Ascorbate Metabolism but Not Glutathione Metabolism. Plant Physiol. 2000, 124, 823-832. [CrossRef] [PubMed]

34. Metsalu, T.; Vilo, J. ClustVis: A Web Tool for Visualizing Clustering of Multivariate Data Using Principal Component Analysis and Heatmap. Nucleic Acids Res. 2015, 43, W566-W570. [CrossRef]

35. Shapiro, S.S.; Wilk, M.B. An Analysis of Variance Test for Normality (Complete Samples). Biometrika 1965, 52, 591-611. [CrossRef]

36. Hartley, H.O. The Maximum F-Ratio as a Short-Cut Test for Heterogeneity of Variance. Biometrika 1950, 37, 308-312. [CrossRef]

37. Abdeldym, E.A.; El-Mogy, M.M.; Abdellateaf, H.R.; Atia, M.A. Genetic Characterization, Agro-Morphological and Physiological Evaluation of Grafted Tomato under Salinity Stress Conditions. Agronomy 2020, 10, 1948. [CrossRef]

38. Cardoso, A.A.; Gori, A.; Da-Silva, C.J.; Brunetti, C. Abscisic Acid Biosynthesis and Signaling in Plants: Key Targets to Improve Water Use Efficiency and Drought Tolerance. Appl. Sci. 2020, 10, 6322. [CrossRef]

39. Ali, S.; Hayat, K.; Iqbal, A.; Xie, L. Implications of Abscisic Acid in the Drought Stress Tolerance of Plants. Agronomy 2020, 10, 1323. [CrossRef]

40. Yamaguchi, S. Gibberellin Metabolism and Its Regulation. Annu. Rev. Plant Biol. 2008, 59, 225-251. [CrossRef]

41. Litvin, A.G.; van Iersel, M.W.; Malladi, A. Drought Stress Reduces Stem Elongation and Alters Gibberellin-Related Gene Expression during Vegetative Growth of Tomato. J. Am. Soc. Hortic. Sci. 2016, 141, 591-597. [CrossRef]

42. Li, J.; Sima, W.; Ouyang, B.; Wang, T.; Ziaf, K.; Luo, Z.; Liu, L.; Li, H.; Chen, M.; Huang, Y.; et al. Tomato SIDREB Gene Restricts Leaf Expansion and Internode Elongation by Downregulating Key Genes for Gibberellin Biosynthesis. J. Exp. Bot. 2012, 63, 6407-6420. [CrossRef] [PubMed]

43. Zhang, Z.; Cao, B.; Li, N.; Chen, Z.; Xu, K. Comparative Transcriptome Analysis of the Regulation of ABA Signaling Genes in Different Rootstock Grafted Tomato Seedlings under Drought Stress. Environ. Exp. Bot. 2019, 166, 103814. [CrossRef]

44. Shohat, H.; Illouz-Eliaz, N.; Kanno, Y.; Seo, M.; Weiss, D. The Tomato DELLA Protein PROCERA Promotes Abscisic Acid Responses in Guard Cells by Upregulating an Abscisic Acid Transporter. Plant Physiol. 2020, 184, 518-528. [CrossRef] [PubMed]

45. Ünyayar, S.; Aktoklu, E.; Büyükasik, Y. The Response to Exogenous Abscisic Acid of the Roots of Notabilis and Its Wild-Type Tomato under Drought Stress. Isr. J. Plant Sci. 2004, 52, 294-299. [CrossRef]

46. Postiglione, A.E.; Muday, G.K. The Role of ROS Homeostasis in ABA-Induced Guard Cell Signaling. Front. Plant Sci. 2020, 11, 968. [CrossRef]

47. Shivakrishna, P.; Reddy, K.A.; Rao, D.M. Effect of PEG-6000 Imposed Drought Stress on RNA Content, Relative Water Content (RWC), and Chlorophyll Content in Peanut Leaves and Roots. Saudi J. Biol. Sci. 2018, 25, 285-289.

48. Liang, G.; Liu, J.; Zhang, J.; Guo, J. Effects of Drought Stress on Photosynthetic and Physiological Parameters of Tomato. J. Am. Soc. Hortic. Sci. 2020, 145, 12-17. [CrossRef]

49. Medyouni, I.; Zouaoui, R.; Rubio, E.; Serino, S.; Ahmed, H.B.; Bertin, N. Effects of Water Deficit on Leaves and Fruit Quality during the Development Period in Tomato Plant. Food Sci. Nutr. 2021, 9, 1949-1960. [CrossRef]

50. Dalal, V.K.; Tripathy, B.C. Water-Stress Induced Downsizing of Light-Harvesting Antenna Complex Protects Developing Rice Seedlings from Photo-Oxidative Damage. Sci. Rep. 2018, 8, 1-16. [CrossRef]

51. Abdallah, M.B.; Trupiano, D.; Polzella, A.; De Zio, E.; Sassi, M.; Scaloni, A.; Zarrouk, M.; Youssef, N.B.; Scippa, G.S. Unraveling Physiological, Biochemical and Molecular Mechanisms Involved in Olive (Olea Europaea L. Cv. Chétoui) Tolerance to Drought and Salt Stresses. J. Plant Physiol. 2018, 220, 83-95. [CrossRef]

52. Singh, J.; Thakur, J.K. Photosynthesis and abiotic stress in plants. In Biotic and Abiotic Stress Tolerance in Plants; Springer: Berlin/Heidelberg, Germany, 2018; pp. 27-46.

53. Cui, J.; Shao, G.; Lu, J.; Keabetswe, L.; Hoogenboom, G. Yield, Quality and Drought Sensitivity of Tomato to Water Deficit during Different Growth Stages. Sci. Agrícola 2019, 77, e20180390. [CrossRef]

54. Falchi, R.; Bonghi, C.; Drincovich, M.F.; Famiani, F.; Lara, M.V.; Walker, R.P.; Vizzotto, G. Sugar Metabolism in Stone Fruit: Source-Sink Relationships and Environmental and Agronomical Effects. Front. Plant Sci. 2020, 11, 1820. [CrossRef] [PubMed]

55. Singh, G.; Kachwaya, D.S.; Kuchi, V.S.; Singh, M.; Singh, J.; Singh, B. Influence of Foliar Application of Mineral Nutrients on Vegetative and Fruit Quality of Strawberry (Fragaria $\times$ ananassa Duch.) Cv. Chandler. J. Plant Sci. Res. 2020, 36, 323-328. [CrossRef] 
56. Kıran, S.; Kuşvuran, Ş.; Talhouni, M.; Sonmez, K.; Ellialtıoglu, Ş.; Özkay, F. Studies on Some Biochemical Changes and Ion Regulation in Some Tomato Genotypes Exposed to Drought Stress. In Proceedings of the VI Balkan Symposium on Vegetables and Potatoes. Acta Hortic. 2014, 1142, 369-376.

57. Rouphael, Y.; Cardarelli, M.; Schwarz, D.; Franken, P.; Colla, G. Effects of drought on nutrient uptake and assimilation in vegetable crops. In Plant Responses to Drought Stress; Springer: Berlin/Heidelberg, Germany, 2012; pp. 171-195.

58. Bista, D.R.; Heckathorn, S.A.; Jayawardena, D.M.; Mishra, S.; Boldt, J.K. Effects of Drought on Nutrient Uptake and the Levels of Nutrient-Uptake Proteins in Roots of Drought-Sensitive and-Tolerant Grasses. Plants 2018, 7, 28. [CrossRef] [PubMed]

59. Dariva, F.D.; Pessoa, H.P.; Copati, M.G.F.; de Almeida, G.Q.; de Castro Filho, M.N.; de Toledo Picoli, E.A.; da Cunha, F.F.; Nick, C. Yield and Fruit Quality Attributes of Selected Tomato Introgression Lines Subjected to Long-Term Deficit Irrigation. Sci. Hortic. 2021, 289, 110426. [CrossRef]

60. Sivakumar, R.; Srividhya, S. Impact of Drought on Flowering, Yield and Quality Parameters in Diverse Genotypes of Tomato (Solanum Lycopersicum L.). Adv. Hortic. Sci. 2016, 30, 3-11.

61. Živanović, B.; Milić Komić, S.; Tosti, T.; Vidović, M.; Prokić, L.; Veljović Jovanović, S. Leaf Soluble Sugars and Free Amino Acids as Important Components of Abscisic Acid-Mediated Drought Response in Tomato. Plants 2020, 9, 1147. [CrossRef]

62. Petrović, I.; Jovanović, Z.; Stikić, R.; Marjanović, M.; Savić, S. Influence of Severe Drought on Leaf Response in ABA Contrasting Tomato Genotypes (Wild Type and Flacca Mutant). Biol. Life Sci. Forum 2020, 41, 8867. [CrossRef]

63. Ijaz, R.; Ejaz, J.; Gao, S.; Liu, T.; Imtiaz, M.; Ye, Z.; Wang, T. Overexpression of Annexin Gene AnnSp2, Enhances Drought and Salt Tolerance through Modulation of ABA Synthesis and Scavenging ROS in Tomato. Sci. Rep. 2017, 7, 1-14.

64. Barupal, T.; Meena, M.; Sharma, K. Inhibitory Effects of Leaf Extract of Lawsonia Inermis on Curvularia Lunata and Characterization of Novel Inhibitory Compounds by GC-MS Analysis. Biotechnol. Rep. 2019, 23, e00335. [CrossRef]

65. Verslues, P.E.; Sharma, S. Proline Metabolism and Its Implications for Plant-Environment Interaction. Arab. Book 2010, 8, e0140. [CrossRef] [PubMed]

66. Pandey, S.; Fartyal, D.; Agarwal, A.; Shukla, T.; James, D.; Kaul, T.; Negi, Y.K.; Arora, S.; Reddy, M.K. Abiotic Stress Tolerance in Plants: Myriad Roles of Ascorbate Peroxidase. Front. Plant Sci. 2017, 8, 581. [CrossRef] [PubMed]

67. Mafakheri, A.; Siosemardeh, A.; Bahramnejad, B.; Struik, P.; Sohrabi, Y. Effect of Drought Stress and Subsequent Recovery on Protein, Carbohydrate Contents, Catalase and Peroxidase Activities in Three Chickpea ('Cicer arietinum') Cultivars. Aust. J. Crop Sci. 2011, 5, 1255-1260.

68. Çelik, Ö.; Ayan, A.; Atak, Ç. Enzymatic and Non-Enzymatic Comparison of Two Different Industrial Tomato (Solanum Lycopersicum) Varieties against Drought Stress. Bot. Stud. 2017, 58, 1-13. [CrossRef]

69. Zhou, R.; Kong, L.; Yu, X.; Ottosen, C.-O.; Zhao, T.; Jiang, F.; Wu, Z. Oxidative Damage and Antioxidant Mechanism in Tomatoes Responding to Drought and Heat Stress. Acta Physiol. Plant. 2019, 41, 20. [CrossRef]

70. Chang, L.; Sun, H.; Yang, H.; Wang, X.; Su, Z.; Chen, F.; Wei, W. Over-Expression of Dehydroascorbate Reductase Enhances Oxidative Stress Tolerance in Tobacco. Electron. J. Biotechnol. 2017, 25, 1-8. [CrossRef]

71. Murshed, R.; Lopez-Lauri, F.; Sallanon, H. Effect of Water Stress on Antioxidant Systems and Oxidative Parameters in Fruits of Tomato (Solanum Lycopersicon L., Cv. Micro-Tom). Physiol. Mol. Biol. Plants 2013, 19, 363-378. [CrossRef]

72. Raja, V.; Qadir, S.U.; Alyemeni, M.N.; Ahmad, P. Impact of Drought and Heat Stress Individually and in Combination on Physio-Biochemical Parameters, Antioxidant Responses, and Gene Expression in Solanum Lycopersicum. 3 Biotech 2020, 10, 1-18. [CrossRef]

73. Yao, X.; Yang, R.; Zhao, F.; Wang, S.; Li, C.; Zhao, W. An Analysis of Physiological Index of Differences in Drought Tolerance of Tomato Rootstock Seedlings. J. Plant Biol. 2016, 59, 311-321. [CrossRef]

74. Sánchez-Rodríguez, E.; Leyva, R.; Constán-Aguilar, C.; Romero, L.; Ruiz, J. Grafting under Water Stress in Tomato Cherry: Improving the Fruit Yield and Quality. Ann. Appl. Biol. 2012, 161, 302-312. [CrossRef]

75. Abdelaziz, M.E.; Atia, M.A.; Abdelsattar, M.; Abdelaziz, S.M.; Ibrahim, T.A.; Abdeldaym, E.A. Unravelling the Role of Piriformospora indica in Combating Water Deficiency by Modulating Physiological Performance and Chlorophyll Metabolism-Related Genes in Cucumis sativus. Horticulturae 2021, 7, 399. [CrossRef]

76. Mokhtar, M.M.; El Allali, A.; Hegazy, M.E.F.; Atia, M.A.M. PlantPathMarks (PPMdb): An interactive hub for pathways-based markers in plant genomes. Sci. Rep. 2020, 11, 1-12. [CrossRef] 